\title{
The Joggins Section
}

\section{LAING FERGUSON}

Department of Geology, Prount Allison University, Sackville, New Brunswick, Canada

\section{Introduction}

The entire succession of the Upper Carboniferous Cumberland coal basin is very well exposed on the cliffs eroded by the $40-50 \mathrm{ft}(12-15 \mathrm{~m})$ tides along the eastern shore of Chignecto Bay near the head of the Bay of Fundy. At the village of Joggins in northwestern Nova Scotia, the lowest of four Iithological facies of the Cumberland Group (Westphalian B) will be examined.

The section has attracted much attention over the last 125 years, and is noteworthy for several reasons. It was one of the first coal-bearing sequences to be described in detail and one where the cyclic nature of sedimentation first attracted attention. The rich bivalve fauna is comparable to that found in the European Coal Measures. The Amphibian Order Microsauria was based on material from Joggins. The fauna of primitive terrestrial reptiles and amphibians, which is found in the bases of erect fossil tree stumps, is world famous (Carroll, 1964). Tracks of a giant terrestrial arthropod (Arthropleura?) have been found in recent years (Ferguson, 1966).

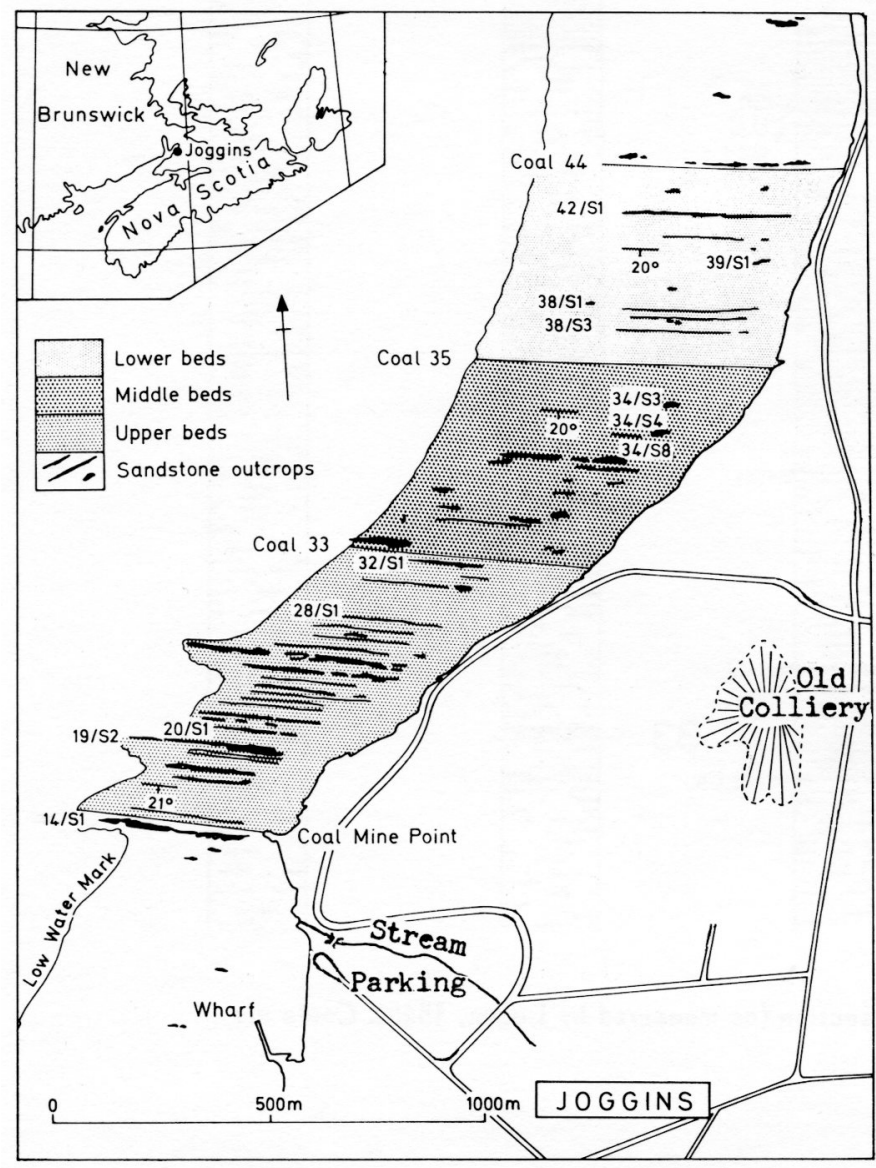

Fig. 1. Geological sketch map of Joggins area (after Duff and Walton, 1973, with permission).
The Lower Fine Coal Bearing Sequence, to be examined between Lower Cove and Joggins Wharf, can be subdivided into three, viz: a lower and an upper division, containing thin impersistent coals and thin limestones among the alternations of sandstone and lutites, and a middle division consisting only of sandstones and lutites (Fig. 1 and Fig. 2). The beds dip to the south at about $20^{\circ}$. The sandstones at present form prominent ridges across the wide littoral zone, and the numerous channel sands are obvious along these ridges as well as in the cliff section. The coals are unusual in that they are occasionally interbanded with limestone or calcareous shale rich in bivalves and ostracods.

The environment of deposition of the beds to be examined has been interpreted by different workers over the last few years as "intermontane terrestrial", "mixed fluvial lacustrine", "fluvial", and most recently as "on-delta" or "delta-plain" (Duff and Walton, 1973). The fauna and lithologies indicate that truly marine conditions were never attained.

The numerous sedimentary structures observable in the section su. est that the delta res. onsible for the beds at Joggins spread across the Cumberland basin towards the north and east during middle Pennsylvanian times, and was bounded by the Caledonian Arch of southeastern New Brunswick to the west and by the Cobequid Arch to the south. The Cumberland Group lies unconformably on the igneous and metamorphic Paleozoic rocks of the Cobequid Arch and lies disconformably on the Westphalian $A$ Riversdale Group to the north.

\section{Numbering System}

The section was measured in detail by Logan (1845) who numbered the coals from the top down. The most recent study of this part of the section was done by Duff and Walton in the summer of 1967 (Duff and Walton, 1973). They used Logan's numbering system with minor modifications, e.g. they numbered the prominent sandstone beds above each of Logan's Coals in upward sequence, e.g. sandstones above Coal 34 would be numbered 34/S1, 34/S2, etc., until Coal 33 is reached (Fig. 1). These numbered sandstone beds are more easily located on the accompanying map (Fig. 1) and on the aerial photographs of the area than are the coals. The section to be examined is approximately from coal \#44 to Coal \#16 in Logan's Division \#4, and has a thickness of approximately $500 \mathrm{~m}$ (Fig. 2).

The following notes are intended as a brief guide to some of the main features to be seen in the section as it will be examined, i.e. starting at Coal 44 at the north end and working up-section to Coal Mine Point and Coal \#16. 


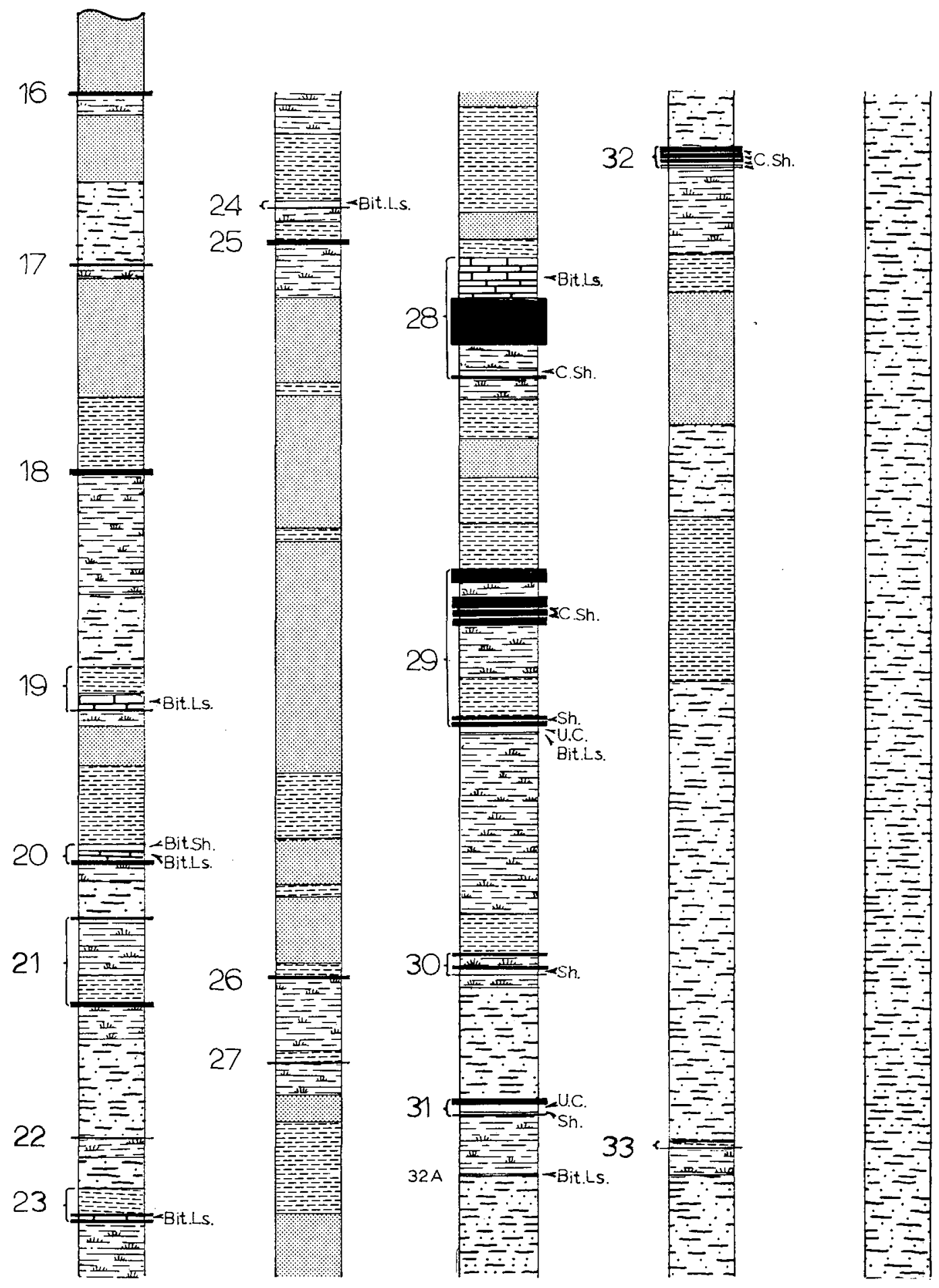

Fig. 2. Sedimentary sequence in part of the Joggins section (as measured by Logan, 1845). Coals are numbered from the top down. 


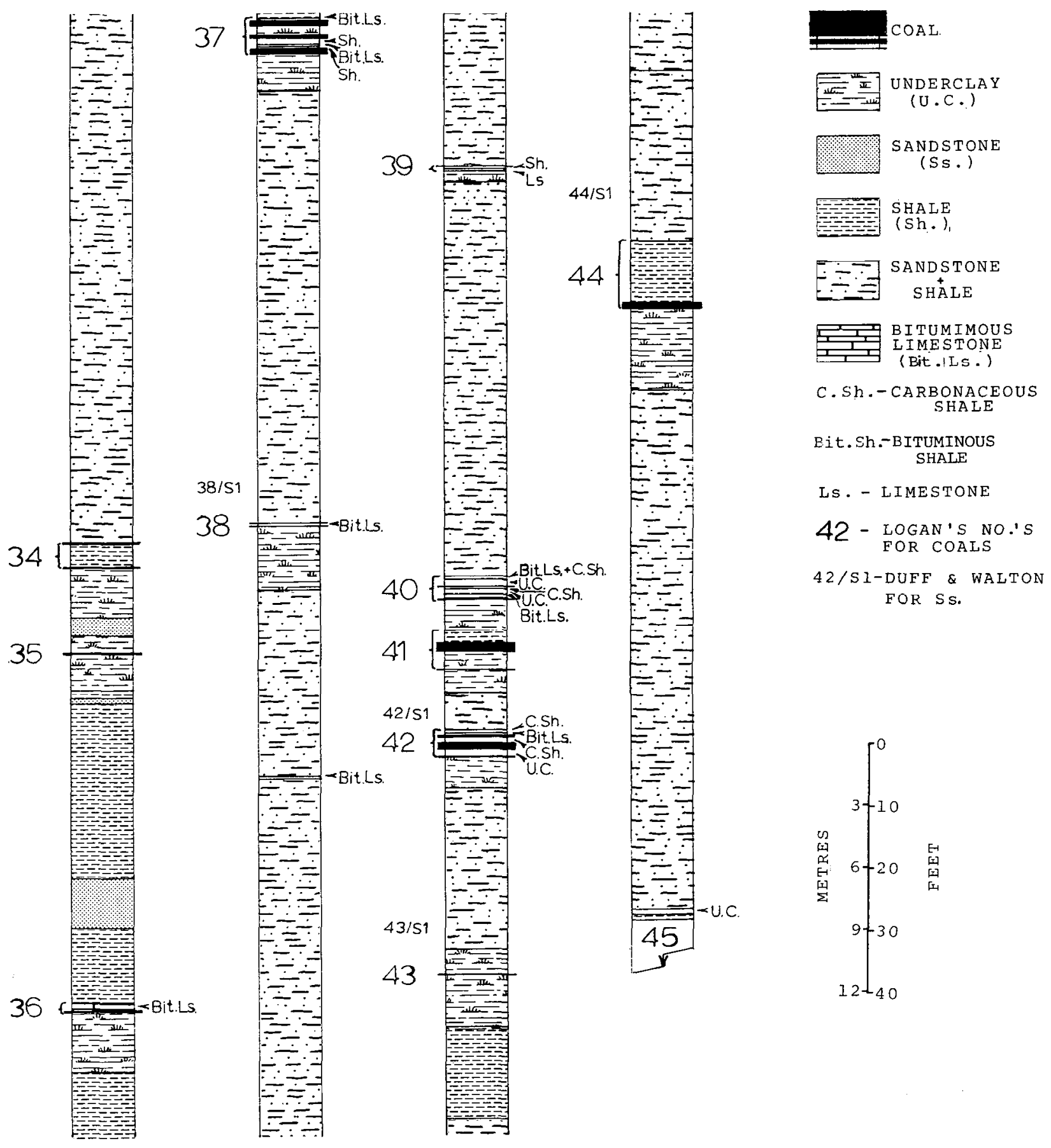

Fig. 2. (Concluded) 
The cliffs at Joggins are very prone to collapse. Rock falls are relatively frequent, and care should be taken not to get too close to any overhanging parts. Please note also that the section may, unfortunately, have to be covered rather quickly on account of the rising tide. N.E. The tidal range is very high in the Bay of Fundy $(40-50 \mathrm{ft}$, $12-15 \mathrm{~m})$.

The Lower Beds (from $10 \mathrm{~m}$ below Coal \#44 to Coal \#35, 160m).

45/S. Cross-hedding may be examined here. It should be noted, however, that paleocurrent data collected by Duff and walton (1973) is not easily interpreted (Fig. 3); but there is a general impression that the delta was built towards the north and east and that the great variability in the directional structures is due to their having been formed from crevasse splays and their channels.

$42 / \mathrm{sl}$. One of the best examples of a typical "cycle" as it is developed at Joggins is that found at Logan"s Coal 42. The original lithological description of these beds is as follows:

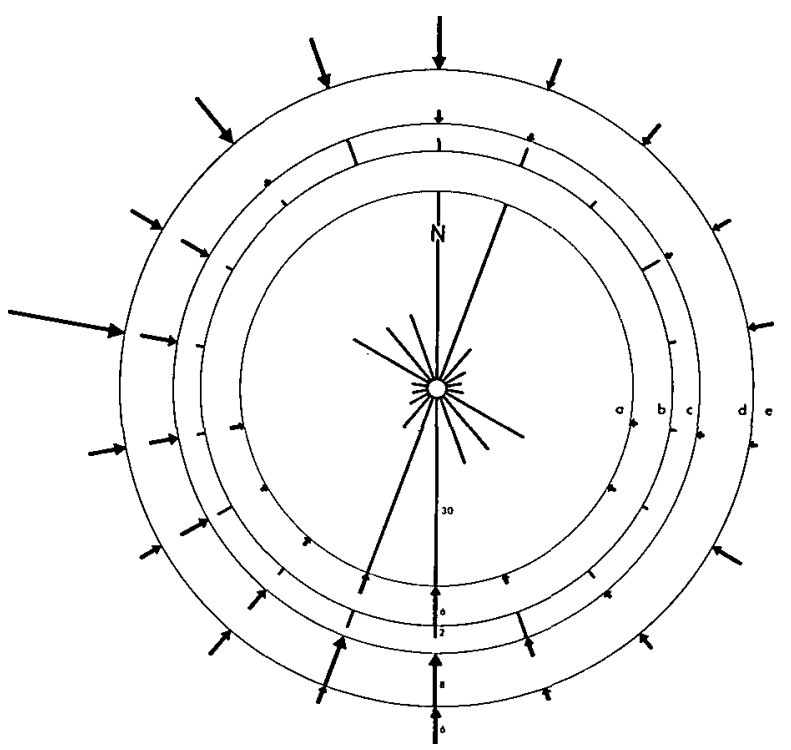

Fig. 3. Palaeocurrent data derived from

a. troughs and crests.

b. sole markings.

c. primary current-lineation.

d. ripple markings and rib and furrow structure.

e. foreset lamination.

Length of line in each category scaled according to number of readings; figures indicate scales. Where known, arrows indicate sense of movement on $360^{\circ}$ scale. In a and c only trend known. (From Duff and Walton, 1973, with permission).
1. Black calcareo-bituminous 08

shale with shells

Black calcareo-bituminous $0 \quad 2$

shale, more calcareous, with

shells

Black calcareo-bituminous $I 0$

shale, less calcareous,

with shells

Carbonaceous shale,

with laminae of coal

Gray argillaceous

shale, with stigmariae

(underclay)

Carbonaceous shale

16

30

Gray argillaceous shale,

0 195)

with stigmariae

(underclay)

Greenish gray argillo-

arenaceous shale, in

alternate hard and soft

ayers, wi stigmariae

leaves (underclay)

Greenish gray sandstone

20

(42/S1)

Dark gray argillaceous

40

shale, studded with

ironstone nodules

42. Carbonaceous shale

07

Black bituminous

02

Iimestone, with shells

replaced by pyrites

\begin{tabular}{|c|c|c|c|c|c|}
\hline Coal & 0 & 3 & & & (8) \\
\hline Carbonaceous shale & 1 & 0 & & & $(30)$ \\
\hline Coal & 1 & 0 & & & $(30)$ \\
\hline $\begin{array}{l}\text { Gra argill-ceous sh-le, } \\
\text { with stigmariae (under- } \\
\text { clay) }\end{array}$ & $I$ & 0 & & & $(30)$ \\
\hline Coal & 0 & 2 & 4 & 2 & $\begin{array}{c}(5, \\
126)\end{array}$ \\
\hline $\begin{array}{l}\text { Dark gray argillaceous } \\
\text { shale, with stigmariae } \\
\text { (underclay) }\end{array}$ & & & 5 & 0 & (152) \\
\hline $\begin{array}{l}\text { Red argillaceous shale, } \\
\text { with some green bands, and } \\
\text { studded with ironstone } \\
\text { balls }\end{array}$ & & & 25 & 0 & $(762)$ \\
\hline
\end{tabular}

Reddish sandstone

10 

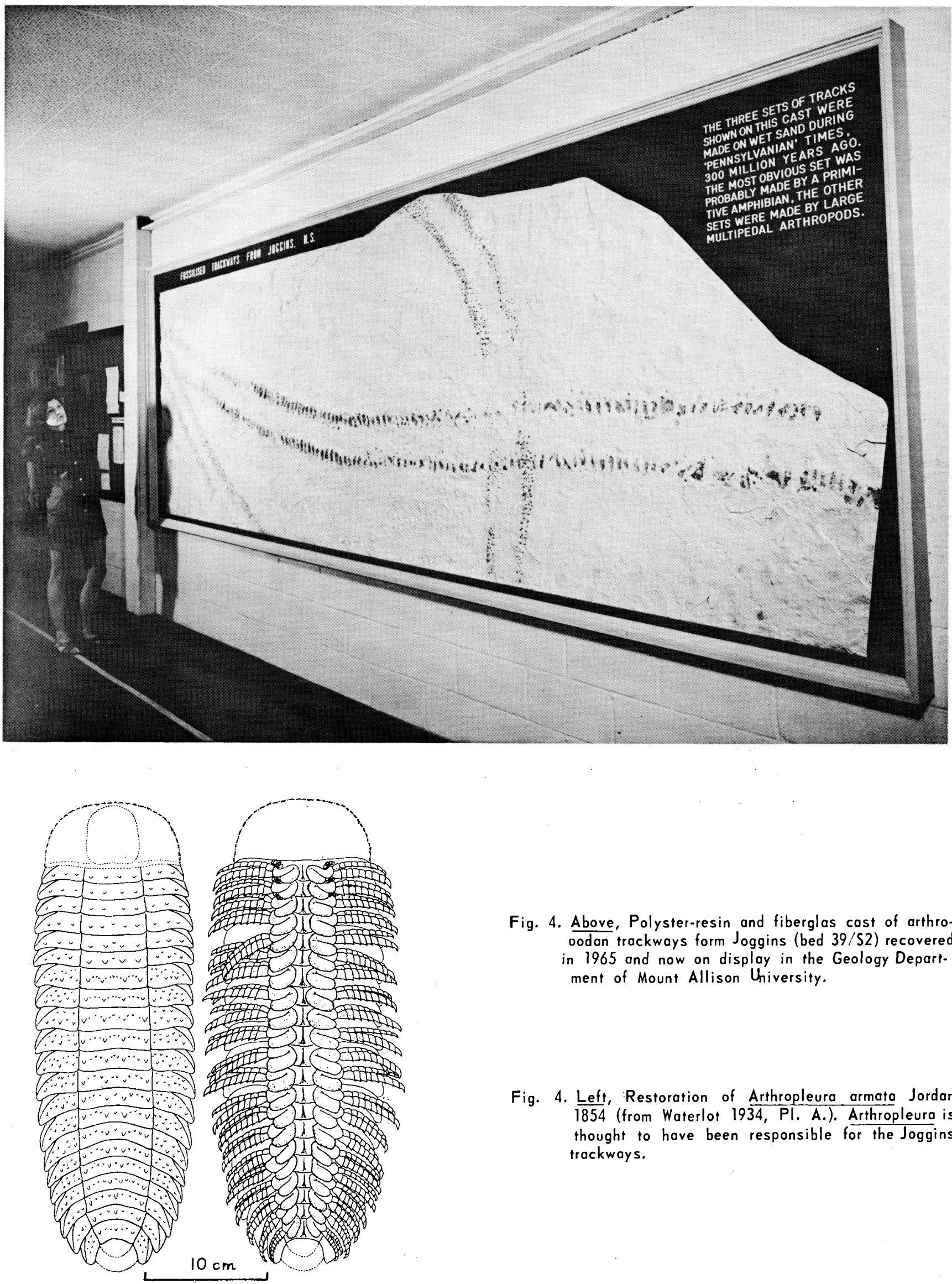

Fig. 4. Above, Polyster-resin and fiberglas cast of arthrooodan trackways form Joggins (bed 39/S2) recovered in 1965 and now on display in the Geology Department of Mount Allison Uhiversity.

Fig. 4. Left, Restoration of Arthropleura armata Jordan 1854 (from Waterlot 1934, PI. A.). Arthropleura is thought to have been responsible for the Joggins trackways. 


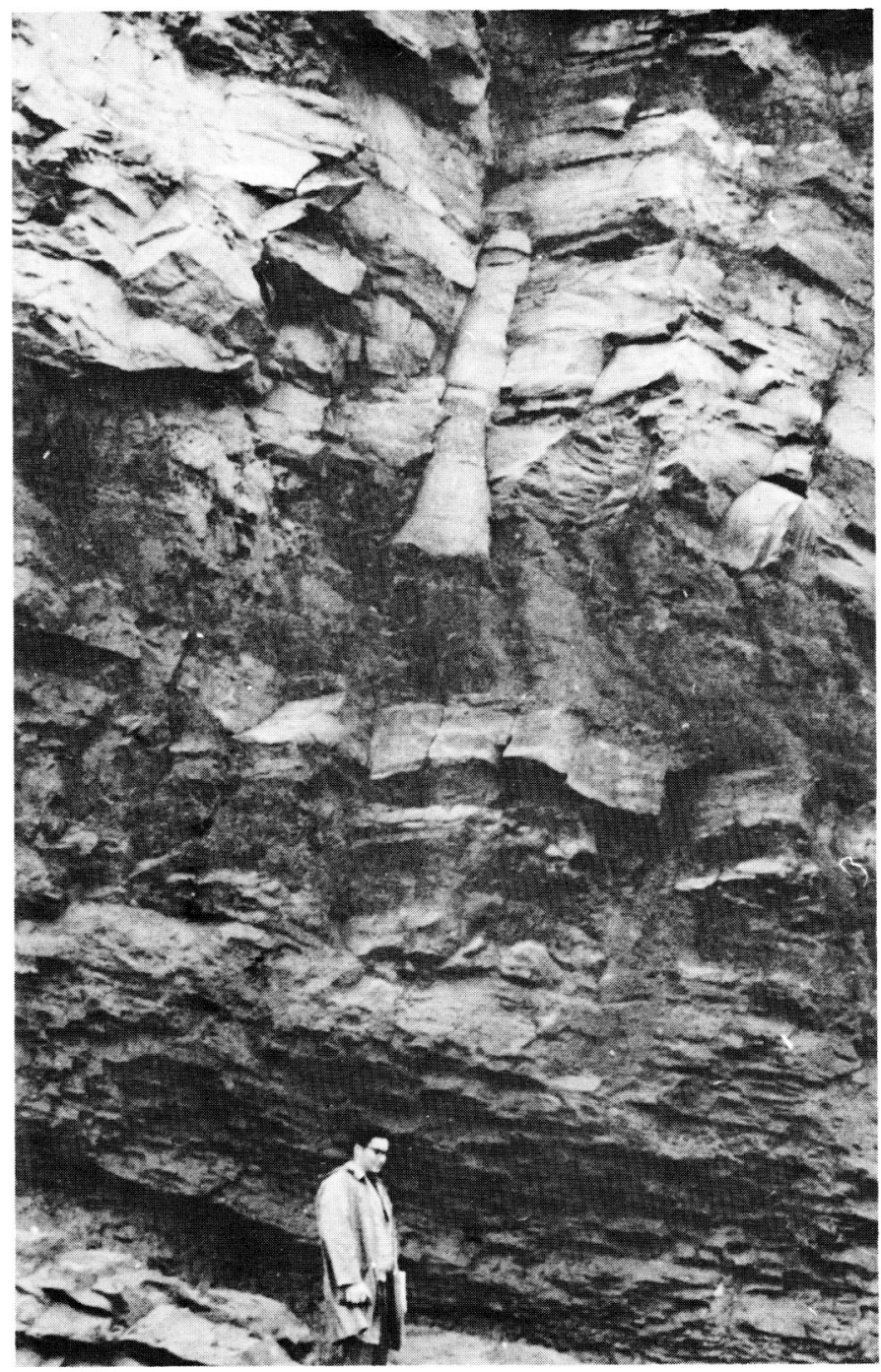

Fig. 5. An erect fossil tree stump, about 7 feet $(2 \mathrm{~m})$ in length, can be seen in the cliff face almost vertically above the standing figure. underside of bed $42 / \mathrm{Sl}$ on the cliff. These commonly occur at the base of such "sheet sands".

$40 / 51$ is a good example of a sheet sandstone thickening into a channel sand (see below).

$39 / \mathrm{S} 2$ and $38 / \mathrm{S} 1$ - 38/S1 is a good example of the "sheet sands". 39/S2 thickens into a channel sand near the base of the cliff. Channels such as this are common, and are readily observed on the beach as prominent wave-resistant masses (see Fig. 1 and aerial photograph - especially between coal 35 and Coal 33).

Large slabs bearing three. sets of: wellpreserved trackways of a large multipedal arthropod were recovered from this spot in 1965, and were most likely from bed $39 / \mathrm{S} 2$. I polyester resin and fiberglas cast of these is on display in the Geology Department of Mount Allison University in Sackville, New Brunswick (Fig. 4). Although no remains of large arthropods have been recovered from the section, it is considered most likely that the giant terrestrial arthropod Arthropleura was responsible for the tracks, as it is found in equivalent strata in both Europe and the U.S.A. Foot prints of small reptiles have also been found in these beds.

38/S2. "Counter ripples" (Duff and walton, their Fig. 5d) may be seen here. These are relatively simple dunes, with ripples on their foreset beds. The current which produced these ripples appears to have been counter to the main movement, and suggests that they were formed during a period of weaker currents.

The coals in the Joggins section are unusual in that they are occasionally interbanded with limestone or calcareous shale. In thin sections, shelly layers and calcareous laminae may be seen in the coal. The limestone associated with the coals are usua $y$ ess than $20 \mathrm{~cm} t c$. F ey are essentially biomicrites of two types: one in which bivalves such as Naiadites and Curvipimula predominate and another rich in Ostracods (e.g. Carbonita spp.). Fossible algal remains have been found only in the bivalve-rich limestone.

The Middle Beds (between coals 35 and $33,125 \mathrm{~m}$ )

Coal 35 is merely a carbonaceous shaly horizon (opposite large cleft in the cliff) and was used by Duff and walton to mark the top of their lower coal-and-limestone-bearing unit. Their "middle beds" are a sequence of sandstones and shales with only a very minor coal (34) and do not merit much attention.

\section{The Upper Beds (from Coal \#33 to Coal \#14, $220 \mathrm{~m}$ )}

The Upper Beds and Lower Beds are characterized by the presence of coals, but have significant differences in that red and mottled mudstones are almost entirely lacking in the Upper Beds although common in the Lower Beds. Limestones 'and fossiliferous mudstones are also much less common in the Upper Beds which are much "sandier". The Lower Beds have a sandstone/shale ratio of only 0.23 as opposed to 0.63 for the Upper Beds. Sandstone seat structures such as primary current lineations, tool marks, prod marks, etc., may be observed on the may be observed at the base of the cliff. Rogers (1965) revised Dawson's species of Naiadites and, after surveying the non-marine bivalve faunas of Eastern North America, suggested that the Cumberland Group was equivalent to the similis-pulchra an modiolaris zones of the European Westphalian.

Large load casts and other sedimentary 
earths occur only in the Upper Beds. Duff and Walton attribute the differences in their three divisions to the relative proximity of migrating distributory channels on the delta.

\section{Fossil Trees}

The Upper Beds are most noteworthy for their content of upright fossil tree stumps of Calomites and Sigilzaria. In previous years (e.g. in 1964), more than thirty stumps of varying length and diameter have been observed in this part of the section (Eig. 5). Cliff erosion is so severe that any particular tree is rarely visible for more than two years.

\section{Mode of Preservation of the Trees}

The bottom of each stump and any preserved roots are commonly surrounded by shale or mudstone and this is overlain by several feet of sandstone which surrounds the lower part of the trunk (Fig. 6B). It is assumed that a period of slow deposition of mud in the interfluves of the delta permitted the establishment of the trees and their growth to maturity. The breaking of a levee (or a sudden more-rapid subsidence of the delta) would bring in coarser sediment (normally confined to the channels) and the base of the tree would be surrounded and the tree killed. The various stages in the preservation of the tree stumps in their growth positions are shown in Figure 7. After the rotting of the interior and the removal of the upper part of the tree, sediment would eventually accumulate until it reached the rim of the trunk and spilled into its interior and rapidly filled it.

Animals traversing the surface of the sediment at this stage might fall into the hollow trunks and be trapped and rapidly buried along with any organisms which had made their homes in the base of the trunk (Fig. 7D). Reptiles and amphibians have been found within the tree stumps (Carroll 1966, 1967).

Petrifaction is rare in the Joggins trees, although one segment of a tree was found in 1964 which had rope-like vascular bundles spiralling up its interior just in from the bark (Fig. 6C). These have been calcified and no doubt indicate more rapid burial of this trunk than of most. Segments of the vascular bundles and a thin section of one may be examined in the Geology Department at Mount Allison.

\section{Differences Between Joggins and the British Coal} Measures

Duff and Walton (1973) attribute the main differences between the Joggins beds and the British coal-bearing sequences to the fact that the Joggins succession accumulated at higher levels of a delta plain than did the British. These differences are: (1) the absence of marine bands at Joggins; (2) the occurrence of only fresh or brackish water limestones; (3) the extreme difficulty of correlation; (4) the abundant red coloration.
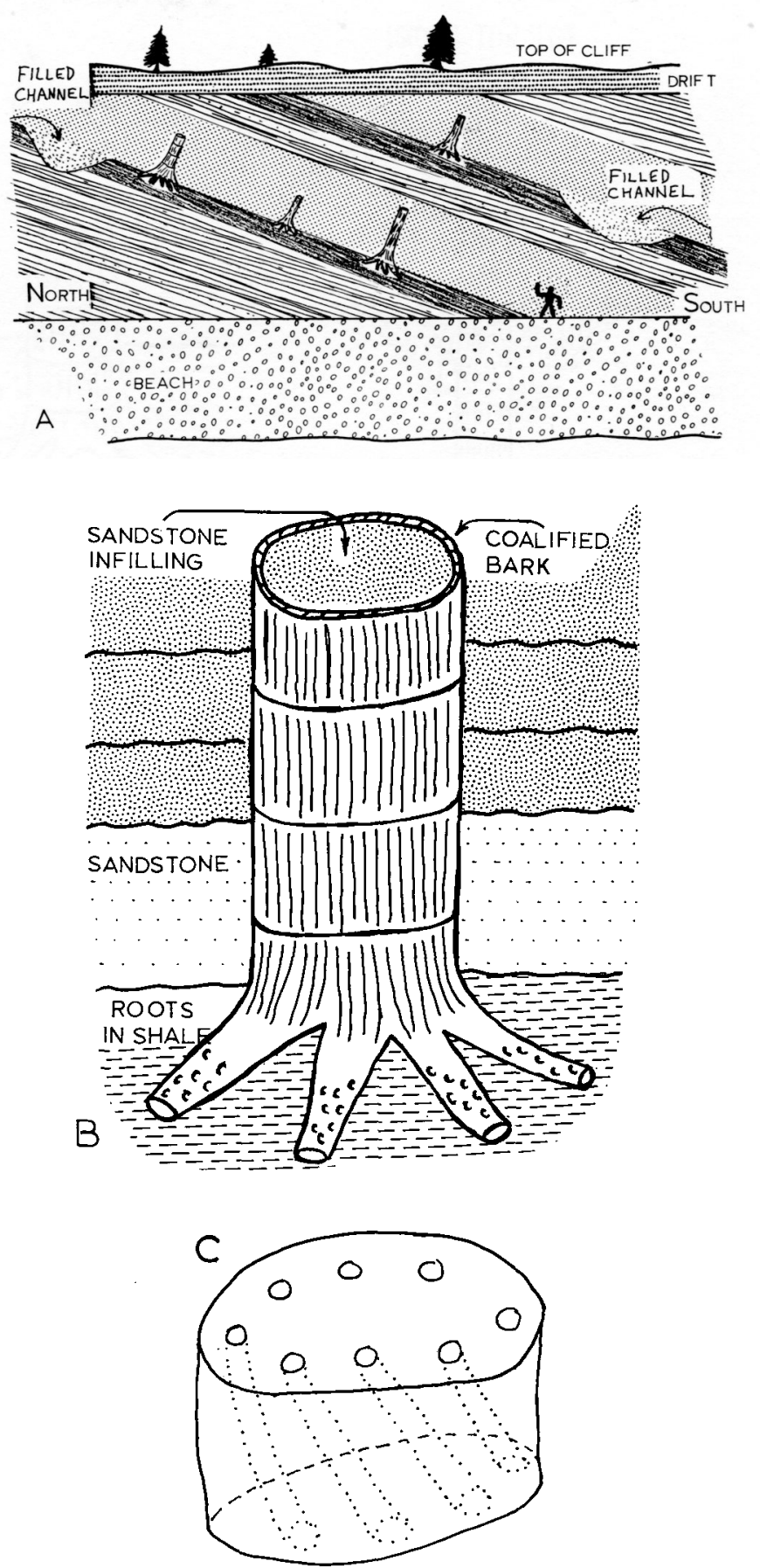

Fig. 6. (a) Mode of occurrence of fossil tree stumps in life position.

(b) Typical tree stump as found at Joggins.

(c) Segment of tree stump showing the position of petrified vascular bundles (diameter approximately $50 \mathrm{~cm}$ ). 


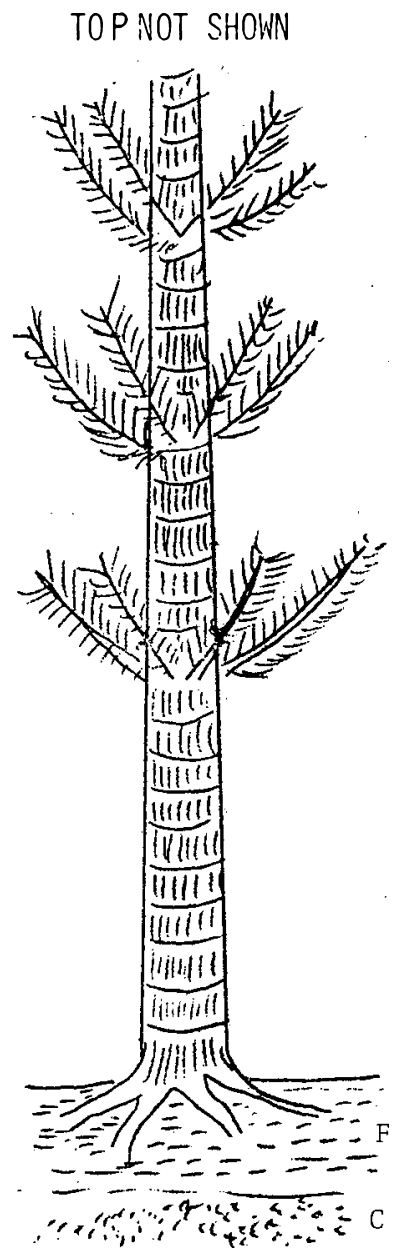

a) CALAMITES TREE growing in fine sediment which had accumulated very slowly.

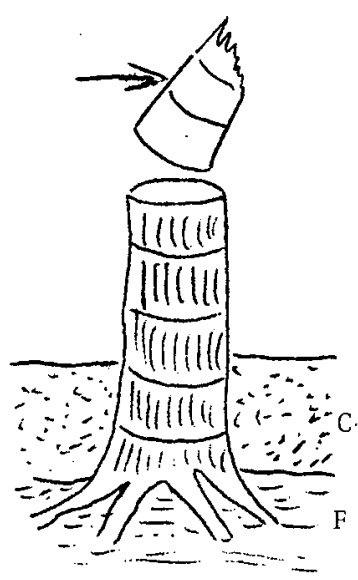

b) Tree is killed by influx

of coarse sediment covering base of trunk. Dead top is blown off easily by wind.

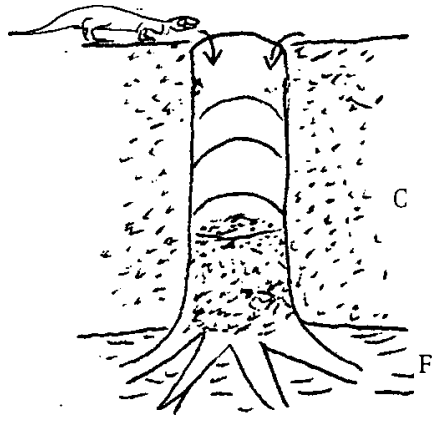

d) See note on right
$C=$ Coarse Sediment

$\mathrm{F}=$ Fine Sediment

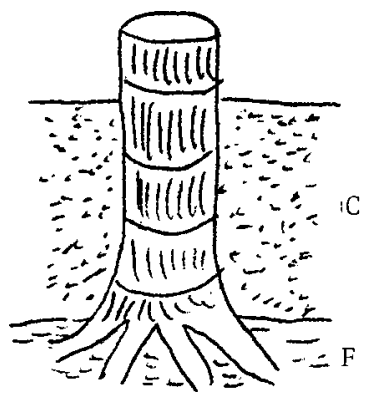

c) The pith core of the tree rots and the rapidly deposited coarse sediment continues to accumulate round the trunk.

d) (on left) Sediment eventually reaches the rim of the hollow trunk and pours in to fill it. It is at this stage that animals may accidentally fall into the trunk and be trapped and subsequently burled. The rocks at Joggins are world famous for the fossilised amphibians \& primitive reptiles which have been found in the bases of the fossil trees.

Once the trunk has been filled with sediment the thin layer of bark surrounding the trunk is slowly converted to coal. The fossil trees are thus sandstone casts of the hollow trunks surrounded by a thin layer of coal.

Fig. 7. Diagrams to illustrate mode of fossilisation of the upright trees at Joggins.

They further postulate that the differences in their three divisions are due to their accumulation at different sites on the delta plain, the Upper Joggins Beds being deposited at a site nearest the sea; the Lower Beds higher in the delta plain; and the Middle Beds probably farther upstream. This appears to accord well with the mode of preservation of the fossil tree stumps postulated above. They would be much more prone to "drowning" and burial at a site nearer the sea where distributory channels were more migratory.

References

CARROLL, R.'L., 1964, The Earliest Reptiles, Jour. Isinnean Soc. (Zool.), 45, 61-83.

, 1966, Microsaurs from the Westphalian B of Joggins, llova Scotia. Proc. Linnean Soc. Lond., 177, I p. 63-67.

, 1967, Labyrinthodonts from the

Joggins Formation. J. Paleont. 41, p. 111-142.

DUFF, D.P. MCL., and WALTON, 1973, Carboniferous Sediments at Joggins, Nova Scotia; in 7 th
Congr. Strat. Geol. Carb., Krefeld, 1971. Compte Rendu, Band 2, p. 365-379.

FERGUSON, LAING, 1966, The Recovery of some large track-bearing slabs from Joggins, N.S., Maritime Sediments, 2, p. 128-130.

LOGAN, W.E., ]845, A section of the Nova Scotia coal measures as developed at the Joggins, on the Bay of Fundy, in descending order, from the neighbourhood of the West Ragged Reef to Minudie, reduced to vertical thickness. Rept. Prog. Geol. Surv. Canada, 1.843, (appendix), p. 92-159.

ROGERS, M.J., 1965, A revision of the species of non-marine bivalvia from the Upper Carboniferous of Eastern North America. J. Paleont., 39 , p. 663-686.

WATERLOT, G., 1934, Etude de la faune continentale du terrain houiller Sarro-Lorrain; en Bassin houiller de la Sarre et de la Lorraine. Etud Gites Miner. Fr., 2. 